\title{
Effect of Slope Position on Soil Properties and Types Along an Elevation Gradient of Arasbaran Forest, Iran
}

\author{
Hossein Rezaei", Ali Asghar Jafarzadeh", Ahmad Alijanpour*, Farzin Shahbazi”, Khalil Valizadeh Kamran ${ }^{1}$ \\ \# Soil Science Department, College of Agriculture, University of Tabriz, Iran. \\ E-mail: hosseinrezaei@tabrizu.ac.ir,ajafarzadeh@tabrizu.ac.ir, shahbazi@tabrizu.ac.ir \\ * Department of Forestry, College of Natural Resources, Urmia University, Iran. \\ E-mail: a.alijanpour@urmia.ac.ir \\ ${ }^{1}$ Department of GIS and Remote Sensing, College of Geography and Planning, University of Tabriz, Iran. \\ E-mail:valizadeh@tabrizu.ac.ir
}

\begin{abstract}
Sustainable development by forest managing need to identify forest ecosystem elements. Forest soil is the most important element of forest ecosystem that has key roles in forest managing. Therefore, studying of soil properties and evolution under different environmental conditions is necessary for sustainable management of forest ecosystems. Spatial variation of soil properties is significantly influenced by some environmental factors that slope position is one of them. The aim of this study was evaluating effects of slope position on forest soil change which was carried out in Arasbaran forest, North-West of Iran. Nine soil profiles were dug, described and sampled in three different parts of an altitudinal transect with same environmental conditions and different slope positions. Then soil samples were analysed physicaly and chemicaly and so classified based on Soil Taxonomy 2014. Also according to obtained results One-way analysis of variance was used to test relations of soil properties and slope positions. This results revealed significant effect of slope positions on thickness of the soil profile and solum, clay, organic carbon and total nitrogen percentages and cation exchange capacity at $5 \%$ level of confidence which lead to change of type, depth and sequence of soil horizons along altitudinal transect. Finally, it has found that slope position not only has important role in soil properties changes and soil evolution but also it can't be refused the various role and influence of same forest stand in different slope positions. Therefore various soils such as Inceptisols, Alfisols and Molisols were observed under different slope positions. Then it can be achieved that, because of special forest vegetation, soil evolution along altitudinal transect of forest ecosystems are differing from other ecosystems. Thus, for forest soil management program it is necessary to consider both of topography and vegetation effect over the area, even if one of them is constant.
\end{abstract}

Keywords - Arasbaran forest; Elevation gradient; Forest soil; Slope position; Soil type.

\section{INTRODUCTION}

Nowadays, there is more attention to forests because of their important role in different aspects of sustainable development. Soil as an important part of forest ecosystems has special condition in stabilize of these ecosystems. Typology of forest soils is important because it has direct relation with forest management decisions. Therefore, it is necessary to study forest soil type relation with environmental conditions. Also, because of the virginity, forest soils are the best choice for studying soil genesis and evolution in relation with environmental conditions. The spatial variation of soil properties is significantly influenced by some environmental factors such as climate, topography, parent materials, vegetation, and disturbance due to human activity [1], [2].

Topography as one of soil forming factors should be considered in local management of soils. Major changes in soil type can occurred over very small difference in distance due to topography. Elevation, slope and aspect are the main elements of topography that can influence on soil development [3]. Stability of the landform directly influences the environmental features such as soil properties and genesis. Among many landform parameters, studying of slope position relation with environmental conditions is important because it has base role in the occurrence of various environmental features and management practices in different ecosystems especially in forests, which was considered about forest soil in this research work. 
There are many assessing about relations of soils and geomorphic surfaces. Some soil physico-chemical and morphological properties such as solum thickness, thickness of the epipedons, clay content, organic carbon, total nitrogen, carbonate, and exchangeable magnesium were significantly different on various slope positions [4]. In the other research work the soil properties on different slope positions were studied and concluded which soils in foot slope and toe slope are contained higher organic carbon and aggregate stability than summit soils [5]. Slope position can alter soil nutrient availability which Chen et al. [6] have reported higher available $\mathrm{Fe}, \mathrm{Mn}, \mathrm{Cu}$ and $\mathrm{Zn}$ in soils of the upper slope positions. Venterea et al. [7] examined patterns of net nitrification rate and $\mathrm{NO}_{3}^{-}$concentration associated with physiographic features in northern hardwood-conifer forest and found that greater rates of net $\mathrm{NO}_{3}{ }^{-}$production, $\mathrm{N}$ mineralization rates, and total $\mathrm{N}$ concentrations were associated with higher plot elevation. Biological traits of soil like physical and chemical properties can be affected by topography. In the other research in northern hardwoodconifer forests greatest microbial biomass, nitrification and denitrification enzyme activities at the highest elevation sites were reported by Bohlen et al. [8]. Soil moisture content was affected by slope position and had influenced on soil mineral weathering and pedogenic processes [9]. Although soil moisture content is most broadly controlled by the amount of rainfall within a year, but there are significant differences with landscape positions [10]. The slope aspect and gradient can control the movement of water and soil material on a hill slope which can contribute to the spatial differences of soil properties [11].

According to above discription, topographic elements effects on soil properties and forming processes, that lead to forming and evolution of various soils in different parts of landscape. Bhaskar et al. [12] compared the soil evolution in different slope position and revealed formation of Ultisols and Entisols in the upper and side slope positions, while soils of valleys take place in Inceptisols order. Khormali et al. [4] studied the soil genesis under different slope position and found catenary evolution along altitudinal transect, which describe the well developed Cambisols (Hapludepts) mainly on summit and non-developed Regosols (Udorthents) on less stable segments of shoulder, backslope and toeslope, where the groundwater saturation caused the soil profile, dominant hydromorphic properties and Gleysols (Endoaquepts) formation.

The Arasbaran forest is one of unique woodland with special ecological properties which is recognized as part of the international network of biosphere reserves. Despite the international fame of this region, there are fewer studies about this forest, which most of them are about the forest vegetations. In the previous research works of Arasbaran forest with a few soils research the absence of soil studies is visible. Therefore to complete the information about their soils, this research work was carried out to assess relation of soil properties and evolution with slope position along elevation gradient. Also, the other objective of present research is typology of the study area soils and finds the base data and information for sustainable management of this forestry region based on soil types.

\section{MATERIALS AND METHODS}

\section{A. Site description and Sampling}

Site study and sampling was carried out on the part of Kaleybar Chai Sofla sub basin in Arasbaran forest which has located in East Azerbaijan province, North-West of Iran, with eastern longitude of $46^{\circ} 39^{\prime}$ to $46^{\circ} 52^{\prime}$ and northern latitude of $38^{\circ} 52^{\prime}$ to $39^{\circ} 53^{\prime}$. Geological formation of this region related to third period of geological age and includes volacano-sedimentry rocks [13]. The main woody species in this area are Hornbeam (Carpinus betulus), Oak (Quercus petrea) and Maple (Acer campestris). According to climatic reports from kaleybar synoptic weather forecasting data station, the average annual precipitation and temperature of the region are $407.13 \mathrm{~mm}$ and $12.54{ }^{\circ} \mathrm{C}$, respectively. Also based on the Amberje climate classification, the climate of the region is semi-humid and moderate [14]. The soil moisture and temperature regimes are Xeric and Mesic respectively.

To achieve the aim of present research work, an altitudinal transect with same environmental conditions except slope positions were selected, and based on the slope position, the study site was split to three parts of the summit, backslope and toeslope. In each part, the study carried out with three soil profiles description and sampling based on the field book for describing and sampling of soils [15] for physical and chemical analysis (Fig. 1).

\section{B. Laboratory analysis and data Interpretation}

In the laboratory after removing large stones, the soil samples were air-dried and passed through a $2 \mathrm{~mm}$ sieve. Particle size distribution and soil texture were determined by the hydrometer method [16]. Electrical conductivity (EC) was determined in extract of saturate soil paste using conductivity meter [17] and soil $\mathrm{pH}$ was measured in saturated soil paste [18]. Organic carbon (OC) was determinate according to the Walkley-Black wet oxidation method corrected by Nelson and Sommers [19]. Cation exchange capacity (CEC) was determined by saturation with $1 \mathrm{M}$ ammonium acetate at $\mathrm{pH}=7.0$ [20]. Calcium carbonate equivalent (CCE) was measured by back titration procedure [21]. Total nitrogen and available phosphorus were determined based on Kjeldahl [22] and Olsen [23] methods. Also available potassium was extracted with $1 \mathrm{M} \mathrm{NH4OAc}$ $(\mathrm{pH}=7.0)$ and were determined by flame photometer [24].

One-way analysis of variance as statistical analysis of the experimental data was accomplished to test relations of soil properties and slope positions using the SPSS software package. The means of soil properties, in different slope positions were compared together by Dunkan's multiple range test. Finally according to results of site and laboratory studies, soils on different parts of study site were classified based on USDA soil taxonomy system [25]. 


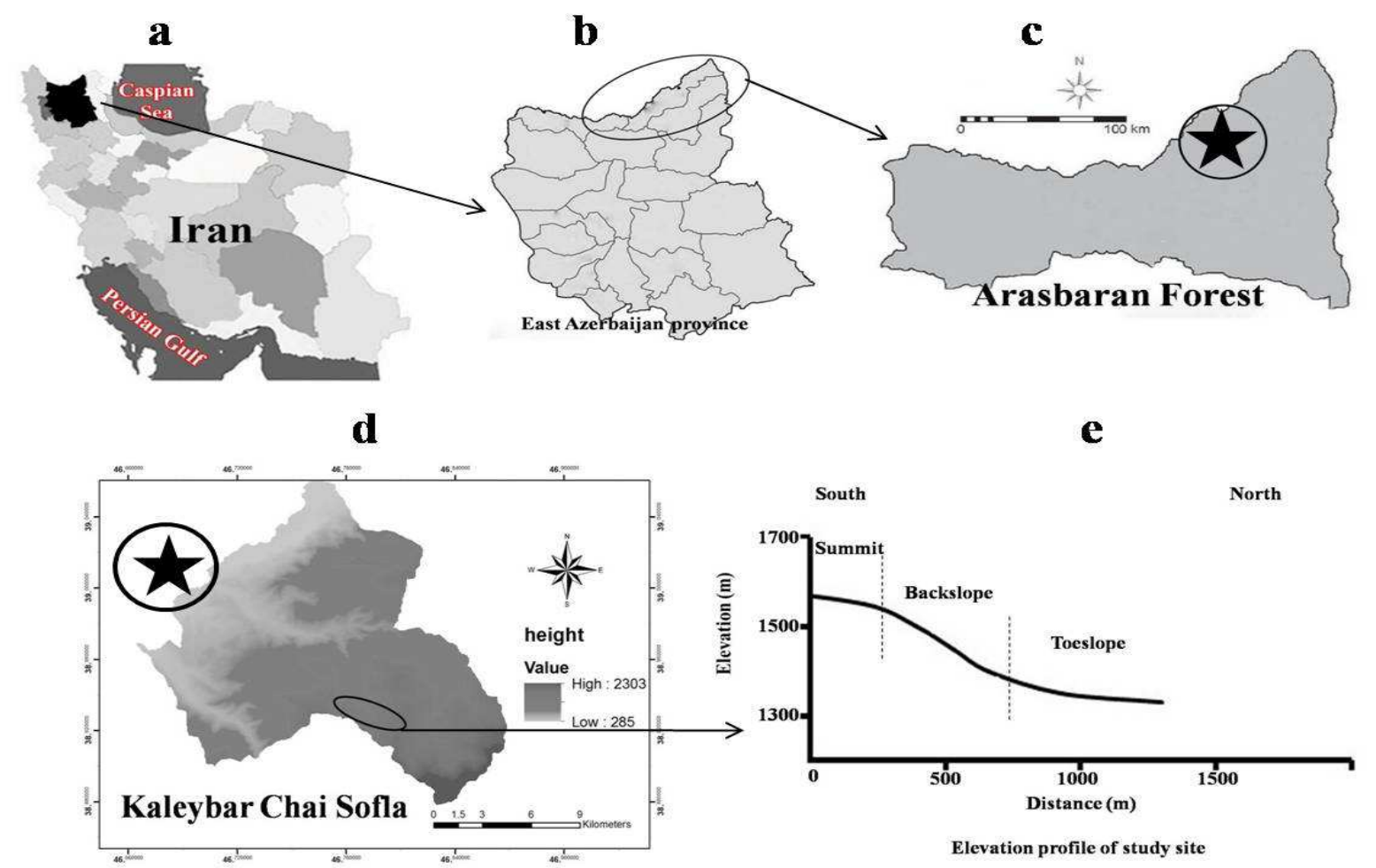

Fig. 1 Location of study site: a) Iran, b) East Azerbaijan province, c) Arasbaran forest, d) DEM of Kaleybar Chai Sofla, e) Elevation profile of study site.

\section{RESULTS AND DISCUSSION}

All profiles in each parts of slope positions had similar morphological characterises; with rare difference. Tables 1 and 2 deal morphological and physico-chemical properties of control profiles as a representative of other ones in each part, while the properties of all nine profiles have used to data interpretation in tables 3 and 4.

Soils in different parts of slope have surface $\mathrm{O}$ horizons with various degrees of organic remnants disintegrations. All over the altitudinal transect, surface soils had dark colour which changed to bright one in depth. Surface horizons of different slope position soils had granular structure and in all parts with increasing soil depth, types of structure were changed to blocky one with low degree of development. Soils in summit and toeslope had cambic horizons which showed undeveloped condition in these parts. Accumulation of clay and presence of clay coating in B horizons of backslope soils revealed that they had Argillic horizons. According to studied results and based on the requirement condition of mollic epipedon, only toeslope soils had this diagnostic horizon.

Table 3 showed physico-chemical properties distribution all of studied soils which used to compare the soils evolution in different slope positions. According to this table summit has lowest profile and solum thickness while backslope has inverse condition. Maximum contents of clay in A and B horizons observed in backslope and the summit has lowest rating. The calcium carbonate equivalent (CCE) ranged from 0 to $16.25 \%$ which were seen in a $\mathrm{Bt}$ and $\mathrm{Bw}$ horizons in backslope and $\mathrm{Bw}$ horizon in toeslope soils respectively. The
$\mathrm{pH}$ and electrical conductivity (EC) values revealed that the soils in this area have neutral reactions and there is no salinity. Because of well forestry vegetation and virginity studied soils have high content of organic carbon and the presence of $\mathrm{O}$ horizons in all studied points confirms this fact. Also the content of organic carbon and $\mathrm{N}$ showed the same trend. In all slope position soils, the available $\mathrm{P}$ and exchangeable $\mathrm{K}$ content are generally greater in surface than the deeper part which this distribution can be consequence of plant residues falling on soil surface.

Based on obtained results, soil properties are different along the altitudinal transect, but some of them have significantly $(\mathrm{p}<0.05)$ difference between slope positions which revealed slope position direct roles in changing soil properties (Table 4). According to statistical analysis soil properties such as profile and solum thickness, clay of A and B horizons, organic carbon content, total nitrogen and cation exchange capacity affected by slope position at $5 \%$ level of confidence. Soil properties that have no significant differences range in various slope positions; have variable sources other than slope position which are same all over the study site. Therefore calcium carbonate equivalent, electrical conductivity, $\mathrm{pH}$, available potassium and available phosphorus are soil properties that can't use as elements of management decisions which are based on slope position in this area. On the other hand for best management decisions based on slope position, it is essential to mean comparison of soil properties affected by this factor significantly, which are showed in Figure 2. 
TABLE I.

Morphological Properties of SElECted CONTROl SoIl ProfiLes.

\begin{tabular}{|c|c|c|c|c|c|c|c|c|c|c|}
\hline \multirow{2}{*}{ Horizon } & \multirow{2}{*}{ Depth $(\mathrm{cm})$} & \multirow{2}{*}{ Boundary $^{\mathrm{a}}$} & \multicolumn{2}{|c|}{ Color } & \multirow{2}{*}{ Structure $^{\mathrm{b}}$} & \multicolumn{3}{|c|}{ Consistence $^{\mathrm{c}}$} & \multirow{2}{*}{ Lime $^{d}$} & \multirow{2}{*}{ Remarks } \\
\hline & & & Moist & Dry & & Dry & Moist & Wet & & \\
\hline \multicolumn{11}{|c|}{ Control Profile 1: summit position. } \\
\hline $\mathrm{Oe}$ & $0-7$ & aw & 10YR3/2 & 10YR3/3 & $3 \operatorname{cgr}$ & $\mathrm{sh}$ & fr & so & - & - \\
\hline A & $7-18$ & $\mathrm{cW}$ & 10YR4/5 & 10YR4/6 & $3 \operatorname{cgr}$ & sh & fr & so & - & - \\
\hline Bw1 & $18-33$ & $\mathrm{cW}$ & $10 \mathrm{YR} 5 / 2$ & 10YR5/3 & $1 \mathrm{mgr}$ & sh & fr & $\mathrm{s}$ & - & - \\
\hline Bw2 & $33-50$ & $\mathrm{cW}$ & $10 \mathrm{YR} 5 / 3$ & $10 Y R 5 / 4$ & $1 \mathrm{fabk}$ & sh & $\mathrm{fr}$ & $\mathrm{s}$ & - & - \\
\hline $\mathrm{C}$ & $50-70$ & - & 10YR3/4 & 10YR6/4 & $\mathrm{sg}$ & - & - & - & es & - \\
\hline \multicolumn{11}{|c|}{ Control Profile 2: backslope position. } \\
\hline $\mathrm{Oa}$ & $0-8$ & aw & 10YR2/1 & $10 \mathrm{YR} 2 / 2$ & $3 \mathrm{mgr}$ & lo & lo & so & - & - \\
\hline A1 & $8-20$ & $\mathrm{cW}$ & 10YR4/3 & 10YR4/4 & $3 \mathrm{cabk}$ & $\mathrm{h}$ & fr & so & - & - \\
\hline A2 & $20-36$ & $\mathrm{cW}$ & 10YR5/4 & 10YR6/4 & 3 cabk & $\mathrm{h}$ & fi & $\mathrm{s}$ & - & - \\
\hline Bt1 & $36-55$ & $\mathrm{cW}$ & 10YR4/6 & $10 Y R 5 / 6$ & 3 cabk & $\mathrm{vh}$ & vfi & Ss & - & Clay coating \\
\hline $\mathrm{Bt} 2$ & $55-100$ & $\mathrm{cW}$ & 10YR4/4 & 10YR5/4 & $2 \mathrm{fabk}$ & $\mathrm{vh}$ & vfi & ss & $\mathrm{e}$ & Clay coating \\
\hline $\mathrm{C}$ & $100-123$ & - & 10YR5/3 & $10 Y R 5 / 4$ & $\mathrm{~m}$ & - & - & - & es & Calcium carbonate \\
\hline \multicolumn{11}{|c|}{ Control Profile 3: toeslope position. } \\
\hline $\mathrm{Oa}$ & $0-8$ & aw & $7.5 \mathrm{YR} 2 / 3$ & $7.5 \mathrm{YR} 3 / 3$ & $2 v f g r$ & lo & lo & so & es & - \\
\hline $\mathrm{A}$ & $8-20$ & $\mathrm{cW}$ & $7.5 \mathrm{YR} 3 / 3$ & $7.5 \mathrm{YR} 4 / 3$ & $1 \mathrm{vfgr}$ & lo & lo & so & es & - \\
\hline Bw1 & $20-39$ & $\mathrm{cW}$ & $5 Y R 3 / 3$ & $5 \mathrm{YR} 4 / 3$ & 2 cabk & $\mathrm{h}$ & vfr & $\mathrm{s}$ & es & - \\
\hline Bw2 & $39-64$ & $\mathrm{cW}$ & $5 \mathrm{YR} 4 / 3$ & $5 \mathrm{YR} 5 / 3$ & $1 \mathrm{mabk}$ & $\mathrm{h}$ & $\mathrm{fr}$ & $\mathrm{s}$ & es & - \\
\hline Bw3 & $64-83$ & $\mathrm{cW}$ & $7.5 \mathrm{YR} 5 / 2$ & $7.5 \mathrm{YR} 5 / 3$ & 1vfabk & $\mathrm{h}$ & fi & $\mathrm{s}$ & ev & - \\
\hline $\mathrm{C}$ & $83-112$ & - & $7.5 \mathrm{YR} 5 / 3$ & $7.5 \mathrm{YR} 5 / 4$ & $\mathrm{~m}$ & - & - & - & ev & Calcium carbonate \\
\hline
\end{tabular}

${ }^{\text {a) }}$ Boundary: a- abrupt, c- clear, w- wavy. / $^{\text {b }}$ Structure: 1- weak, 2- moderate, 3- strong; vf- very fine, f- fine, c- coarse; gr- granular, abk- angular blocky, sgsingle grain, m- massive $\left./{ }^{c}\right)$ Consistence: lo- loose, so- soft, sh- slightly hard, h- hard, vh- very hard, vfr- very friable, fr- friable, fi- firm, vfi- very firm, ssslightly sticky, s- moderately sticky. $/^{\mathrm{d})}$ Lime: e- slightly effervescent, es- strongly effervescent, ev- violently effervescent.

TABLE II

Physico-ChemicAl Properties of SElected Control SoIl PROFiLes.

\begin{tabular}{|c|c|c|c|c|c|c|c|c|c|c|c|c|}
\hline Horizon & $\begin{array}{l}\text { Clay } \\
(\%)\end{array}$ & $\begin{array}{l}\text { Silt } \\
(\%)\end{array}$ & $\begin{array}{l}\text { Sand } \\
(\%)\end{array}$ & Texture $^{a}$ & $\begin{array}{c}\mathrm{CCE}^{\mathrm{b}} \\
(\%)\end{array}$ & $\begin{array}{l}\mathrm{OC}^{\mathrm{c}} \\
(\%)\end{array}$ & $\begin{array}{l}\mathrm{N} \\
(\%)\end{array}$ & $\begin{array}{c}\mathrm{K} \\
\text { (meq.100gr } \\
\text { (moil) }\end{array}$ & $\begin{array}{c}\mathrm{P} \\
\text { (mg.kg-1 soil) }\end{array}$ & $\mathrm{pH}$ & $\begin{array}{c}\mathrm{EC} \\
\left(\mathrm{dS} . \mathrm{m}^{-1}\right)\end{array}$ & $\begin{array}{c}\mathrm{CEC}^{\mathrm{d}} \\
\left(\mathrm{cmolc}^{\mathrm{kgg}} \mathrm{kg}^{-1}\right)\end{array}$ \\
\hline \multicolumn{13}{|c|}{ Control Profile 1: summit position. } \\
\hline $\mathrm{Oe}$ & 25 & 25 & 50 & SCL & 5.75 & 14.28 & 1.43 & 1.09 & 56.79 & 7.01 & 1.22 & 29.22 \\
\hline A & 17.5 & 32.5 & 50 & $\mathrm{~L}$ & 4 & 4.39 & 0.44 & 0.32 & 5.62 & 7.02 & 0.78 & 27.92 \\
\hline Bw1 & 22.5 & 27.5 & 50 & SCL & 4.25 & 4.39 & 0.44 & 0.23 & 6.57 & 6.92 & 0.53 & 26.28 \\
\hline Bw2 & 27.5 & 25 & 47.5 & SCL & 4.75 & 4.39 & 0.44 & 0.2 & 18.45 & 6.75 & 0.52 & 25.8 \\
\hline $\mathrm{C}$ & 20 & 25 & 55 & SCL & 15.25 & 3.4 & 0.34 & 0.19 & 4.54 & 7.49 & 0.5 & 25.66 \\
\hline \multicolumn{13}{|c|}{ Control Profile 2: backslope position. } \\
\hline $\mathrm{Oa}$ & 22.5 & 27.5 & 50 & SCL & 4 & 9.73 & 0.95 & 1.33 & 41.23 & 7.15 & 1.49 & 26.07 \\
\hline A1 & 27.5 & 25 & 47.5 & SCL & 4 & 5.78 & 0.54 & 0.68 & 11.25 & 7.21 & 0.7 & 21.42 \\
\hline $\mathrm{A} 2$ & 35 & 20 & 45 & SCL & 3.75 & 3.4 & 0.34 & 0.53 & 4.38 & 6.68 & 0.43 & 22.24 \\
\hline Bt1 & 42.5 & 20 & 37.5 & $\mathrm{C}$ & 4.25 & 3.8 & 0.36 & 0.65 & 3.49 & 6.87 & 0.43 & 26.35 \\
\hline Bt2 & 52.5 & 15 & 32.5 & $\mathrm{C}$ & 7.25 & 2.61 & 0.24 & 0.72 & 2.84 & 7.42 & 0.51 & 26.55 \\
\hline $\mathrm{C}$ & 37.5 & 25 & 37.5 & $\mathrm{CL}$ & 15.25 & 2.02 & 0.2 & 0.53 & 2.84 & 7.48 & 0.35 & 21.21 \\
\hline \multicolumn{13}{|c|}{ Control Profile 3: toeslope position. } \\
\hline $\mathrm{Oa}$ & 27.5 & 27.5 & 45 & SCL & 12.75 & 4.39 & 0.42 & 0.72 & 9.53 & 7.46 & 0.6 & 30.72 \\
\hline A & 32.5 & 25 & 42.5 & $\mathrm{CL}$ & 13 & 1.26 & 0.13 & 0.94 & 2.36 & 7.44 & 0.49 & 30.17 \\
\hline Bw1 & 35 & 30 & 35 & CL & 16.25 & 1.65 & 0.17 & 0.31 & 1.75 & 7.44 & 0.42 & 30.79 \\
\hline Bw2 & 35 & 25 & 40 & $\mathrm{CL}$ & 10 & 0.26 & 0.2 & 0.3 & 0.92 & 7.26 & 0.36 & 27.44 \\
\hline Bw3 & 32.5 & 35 & 32.5 & CL & 3.75 & 0.06 & 0 & 0.3 & 1.88 & 7.44 & 0.31 & 27.99 \\
\hline $\mathrm{C}$ & 35 & 30 & 35 & CL & 9.25 & 0.06 & 0 & 0.28 & 4.69 & 7.2 & 0.31 & 29.28 \\
\hline
\end{tabular}

Thickness of soil profile and solum are important because of their important role in supporting of plants and soil forming processes. Based on statistical analysis the highest thickness of soil profile and solum was obtained in backslope which was not significantly different from toeslope, while there was significant difference between summit and other positions (Fig. 2-a, 2-b). According to results, toeslope had deep soil profiles because it had low slope gradient and received deposits from upper slope positions. There are many assessing about relation of slope position with soil depth that confirms previous condition for toeslope which soils depth were decreased by increasing slope gradient [4], [26], [27]. Although slope positions with high gradient usually have undeveloped and shallow soils but sometimes there are stable high gradient slope with mature and deep soils. Regarding backslope, our findings similar to Drees et al. [28] results, that presented this exception mode and inverse status with other researches [4], [26], [27]. This exception mode occurs when rating of soil forming processes are higher than degradation or erosion rates on slopes. Studied transect was in the north facing slope, which backslope received lower solar radiation and had more available moisture which led to higher rating of soil forming and deep soils. Also, because of higher moisture the vegetation of this part is denser than other positions which help to soil stability and development. 
TABLE III

Distribution of Physico-CHEMICAL PROPERTIES of STUDIED SOILS

\begin{tabular}{|c|c|c|c|c|c|c|c|c|c|}
\hline Slope position & \multicolumn{3}{|c|}{ Summit } & \multicolumn{3}{|c|}{ Backslope } & \multicolumn{3}{|c|}{ Toeslope } \\
\hline Data distribution & $\min$ & $\max$ & mean & $\min$ & $\max$ & mean & $\min$ & $\max$ & mean \\
\hline Profile thickness $(\mathrm{cm})$ & 40 & 78 & 62.6 & 123 & 140 & 131.6 & 95 & 120 & 109 \\
\hline Solum thickness $(\mathrm{cm})$ & 12 & 43 & 30.6 & 92 & 105 & 97 & 58 & 91 & 74.6 \\
\hline Clay of B horizons $(\%)$ & 12.5 & 27.5 & 19.37 & 32.5 & 52.5 & 41.4 & 27.5 & 40 & 35 \\
\hline $\mathrm{CCE}^{\mathrm{a}}$ of A horizons $(\%)$ & 1.25 & 5 & 3.6 & 3.5 & 4.25 & 3.87 & 3.25 & 13 & 8 \\
\hline CCE of B horizons (\%) & 3.75 & 6.25 & 4.75 & 0 & 7.5 & 3.42 & 0.25 & 16.25 & 6.4 \\
\hline $\mathrm{OC}^{\mathrm{b}}(\%)$ & 2.42 & 16.26 & 6.37 & 0.44 & 9.74 & 3.65 & 0.06 & 13.84 & 3.07 \\
\hline $\mathrm{N}(\%)$ & 0.24 & 1.63 & 0.64 & 0.04 & 0.96 & 0.36 & 0.006 & 1.38 & 0.3 \\
\hline $\mathrm{K}$ (meq.100 $\mathrm{gr}^{-1}$ soil) & 0.19 & 2.11 & 0.57 & 0.32 & 1.33 & 0.66 & 0.27 & 2.14 & 0.68 \\
\hline $\mathrm{P}$ (mg.kg ${ }^{-1}$ soil) & 2.42 & 88.84 & 18.38 & 1.68 & 41.23 & 9.76 & 0.92 & 56.36 & 11.51 \\
\hline $\mathrm{pH}$ & 6.5 & 7.5 & 7 & 6.6 & 7.58 & 7.17 & 6.28 & 7.46 & 7.16 \\
\hline $\mathrm{EC}\left(\mathrm{dS} . \mathrm{m}^{-1}\right)$ & 0.38 & 1.65 & 0.76 & 0.25 & 1.52 & 0.58 & 0.31 & 1.21 & 0.54 \\
\hline $\mathrm{CEC}^{\mathrm{c}}\left(\mathrm{cmolc} \cdot \mathrm{kg}^{-1}\right)$ & 13.03 & 38.21 & 22.83 & 21.07 & 26.55 & 23.39 & 25.18 & 31.47 & 28.92 \\
\hline
\end{tabular}

a) Calcium Carbonate Equivalent. b) Organic Carbon. c) Cation Exchange Capacity.

TABLE IV

VARIANCE ANALySES of SOIL PROPERTIES in DifFERENT SLOPE POSITIONS

\begin{tabular}{|c|c|c|c|c|c|}
\hline Property & Sum of Squares & df & Mean Square & F & Sig. \\
\hline Profile thicknes (cm & 7421.556 & 2 & $3710.778^{*}$ & 17.485 & 0.003 \\
\hline Solum thicknes (cm) & 6834.889 & 2 & $3417.444^{*}$ & 17.328 & 0.003 \\
\hline Clay of A horizons (\%) & 495.238 & 2 & $247.619^{*}$ & 12.474 & 0.007 \\
\hline Clay of B horizons (\%) & 1117.390 & 2 & $558.695^{*}$ & 11.804 & 0.008 \\
\hline CCE of A horizons (\%) & 35.561 & 2 & 17.781 & 2.118 & 0.201 \\
\hline CCE of B horizons (\%) & 8.380 & 2 & 4.190 & 0.487 & 0.637 \\
\hline OC (\%) & 16.534 & 2 & $8.267^{*}$ & 24.230 & 0.001 \\
\hline N (\%) & 0.163 & 2 & $0.82^{*}$ & 25.436 & 0.001 \\
\hline K (mg.100gr (moil) $^{-1}$ s $\left(\mathrm{mg}^{-1}\right.$ soil) & 0.51 & 2 & 0.26 & 2.783 & 0.140 \\
\hline pH & 33.478 & 2 & 16.739 & 3.598 & 0.094 \\
\hline EC (dS. m-1) & 0.01 & 2 & 0.005 & 0.059 & 0.944 \\
\hline CEC (cmolc.kg-1) & 0.02 & 2 & 0.01 & 2.179 & 0.194 \\
\hline
\end{tabular}

Significant at $5 \%$ level.

Clay percent and removal are important factors for soil fertility and evolution. From figure 2-c and 2-d, it can be calculated that the clay percent of $\mathrm{A}$ and $\mathrm{B}$ horizons in the backslope is higher than others. Based on statistical results there was no significant difference between backslope and toeslope clay content but summit had difference condition. Although the maximum clay content should be in summit [29], but higher amount of clay in lower slope position have resulted by clay translocation from upper to lower positions and its deposition in shoulder, backslope or toeslope positions [30]. Also, formed Argillic horizons in backslope showed the high clay content in this position which have resulted from clay translocation, transformation and leaching through root channels [31].

Exclusive role of soil organic carbon caused to identify as base soil properties which studying in any research of soil. Always soil organic carbon distribution follows from vegetation status because plant residues are the main source of soil organic matter. Evaluation of organic component in this research work revealed the descending order of organic carbon from summit, backslope and toeslope respectively, that each slope position had significant difference with other positions (Fig. 2-e). All over the study site had same kind of tree but their density were different in each slope positions. Along with Long [32] reported results, backslope had denser trees rather than summit and this fact refused previous hypothesis in last paragraph about plant and soil organic carbon distribution relation. Although backslope had higher amount of plant residues, decomposition rate of organic matter in this position is slower than summit because of wasn't safe environmental condition for plant residues integration and they remind intact on soil surface. Therefore it can be achieved that regardless of plant residues, other environmental conditions such as moisture, temperature, microbial activity and etc have important roles in soil organic carbon content. Nitrogen as essential nutrient had important role in plants growth which Figure 2-f showed its distribution in different slope position. According to these results total $\mathrm{N}$ had similar distribution with organic carbon which Khormali et al. [4] findings support this result.

CEC is one of soil properties which used in soil fertility management. Usually clay and organic matter are the main sources of soil CEC [33]; on the other hand CEC controlled by them. Therefore distribution of CEC in different slope positions should be followed by clay and organic matter distribution patterns. In this research, the results of statistical analysis revealed that all of CEC had significantly difference between slope positions but it hasn't similar distribution pattern with clay or organic matter because both of them interactions affected on CEC (Fig. 2-g). Toeslope and summit had highest and lowest CEC respectively. 
a

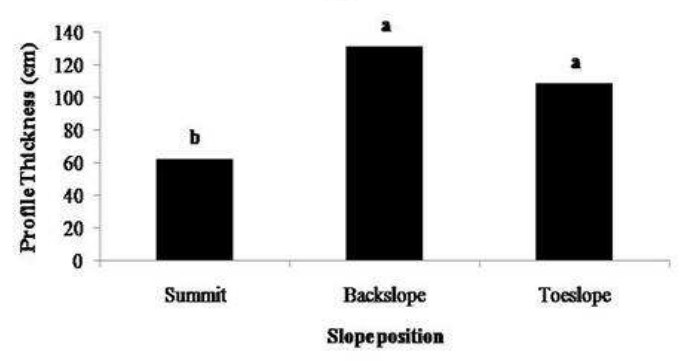

c

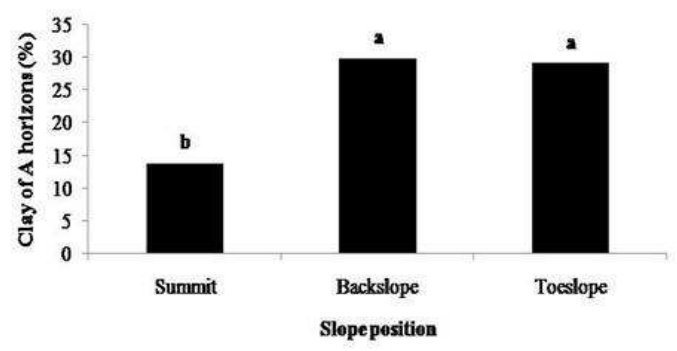

e

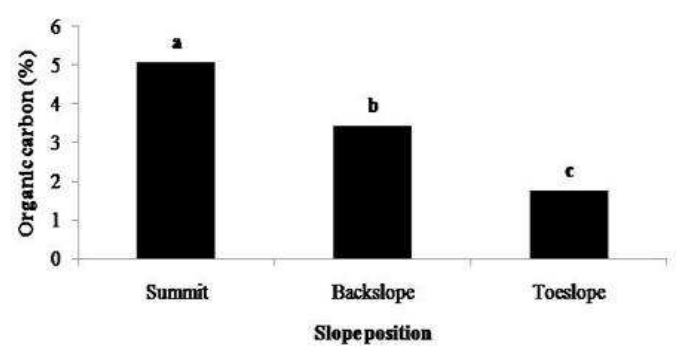

b

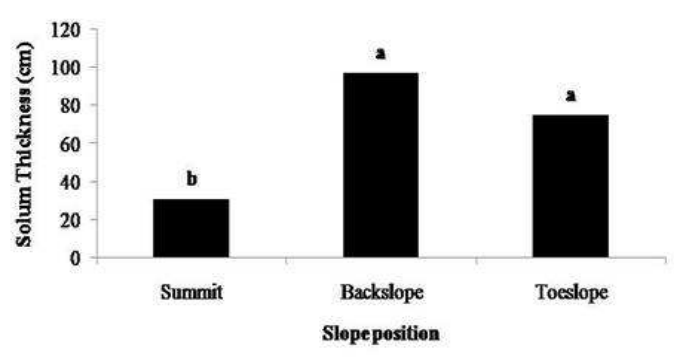

d

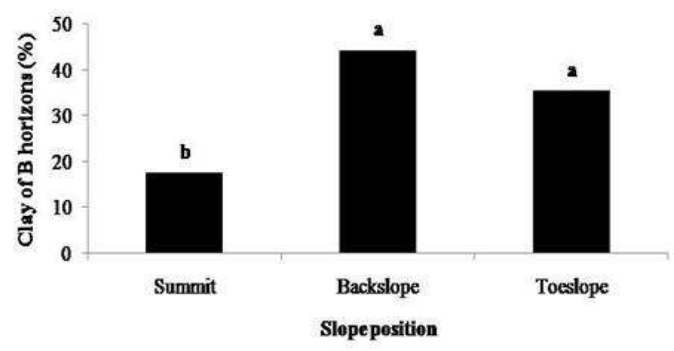

f

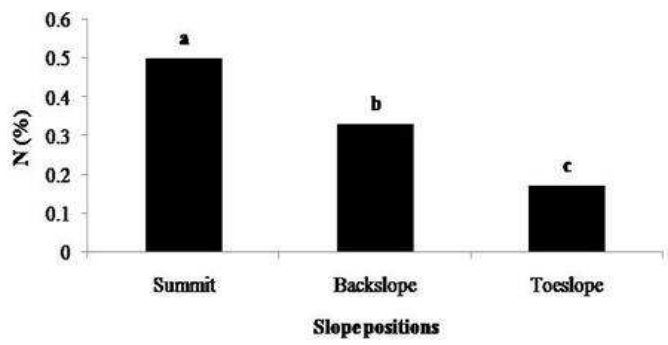

g

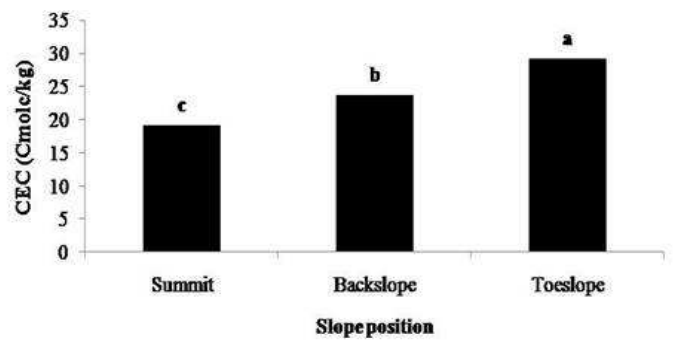

Fig. 2 Mean comparison of sol properties in different slope positions.

Although summit had maximum amount of OC, its clay content is lower than toeslope and based on CEC amount in these positions, it can be found that in this region the importance role of clay in CEC control was rather than OC which Bezabih et al. [34] results support the obtained results about more significant role of clay content in CEC amount of different slope positions. Also comparing of backslope and summit about clay, organic matter and CEC of soil confirm this fact. Statistically backslope and toeslope had same clay content but backslope had significant high amount of OC. Then it seems backslope should be had higher CEC while results showed inverse condition. In the parallel explanation with results of Hseu et al. [31] which showed the formation of various clay minerals in different slope position, the results revealed the role of clay mineral kinds and presence of clay mineral with high CEC in toeslope. Generally based on CEC interpretation in the study area clay content is the most important element that should be 
considered for soil CEC management. Also it can be understood that slope position influenced on clay mineral and can lead to transformation of them which mineralogical studies can help to clarify this subject.

According to the obtained results, physical and chemical analyses, soils classified on the basis of USDA soil taxonomy system (2014), which representative soil profile classification in each slope position have reported in table 5. Soil classification showed evolution of several kinds of soils such as Inceptisols, Alfisols and Molisols in various slope positions. The soil diversity along studied elevation profile is the results of soil properties change and various diagnostic horizons formation.

The soil of summit was Inceptisols with cambic horizons and undeveloped conditions. Due to unsuitable environmental condition for soil forming there hasn't occurred dominant pedogenesis processes in this position as well as weathering, structure formation and organic matter accumulation were the soil forming processes happened in this position. Comparing of slope positions in study site showed sparse vegetation in summit because of ecological reasons, so land surface received high solar radiation which caused to decrease soil moisture. Inasmuch many of soil pedogenesis processes is relating to soil moisture [35], summit soils were immature and undeveloped considering soil moisture limitation.

Principally backslope should be have undeveloped soils but the present work results revealed that it contained significant amounts of clay and in accommodated with results of other researchers [36], [37] and [38] showed presence of Argillic horizons and evolution of Alfisols. It seems that backslope was wetter than summit due to dense vegetation and gain less solar radiation for placement which caused to formation of Alfisols as developed soil [36]. Existence of moisture and pedofeature related to clay translocation described lessivage as a main pedogenesis processes in the backslope. Also it is essential considering to plant roots role in soil stability and evolution on high gradient positions like this studied site [39].

Mollic epipedon was seen in toeslope and Mollisols identified as dominant soil of this position. This soil occur in a wide range of landscapes with different slope, therefore slope position dosen't have direct role in Mollisols evolution, although it has indirect impress by vegetation distribution pattern. This soil forming influenced by organic matter presence and its mixing with mineral material which happened in Melanisation process as well as accumulation of organic matter and humification which occurred in this regard [40]. The obtained results in same opinion with Aydinalp [41] revealed that Mollisols evolution is in related with optimal condition of temperature, moisture and biological activity to preparing safe status for discussed pedogenesis processes, which these requirements provided in toeslope. High value of CEC and darker colour were the evidence of Mollisols in toeslope.

Briefly, some of soil properties influenced by slope position and change in the range of these properties lead to forming of different diagnostic horizons and soils along altitudinal transect. As seen, there are unusual catenary evolution of soils in this region which showed presence of development soil in high gradient position and immature soil in gentle slopes. This point affirmed that evolution of soils in the study site not influencing only by slope position and other environmental factors have direct or indirect role in soil forming which vegetation is the most important ones.

TABLE V

Classification of Studied SoILS in Control Profiles

\begin{tabular}{|c|c|}
\hline Profile position & $\begin{array}{l}\text { Soil classification (keys to soil taxonomy, } \\
\text { 2014) }\end{array}$ \\
\hline $\begin{array}{l}\text { Located in summit } \\
\text { position }\end{array}$ & $\begin{array}{l}\text { Fine-loamy, mixed, superactive, mesic, } \\
\text { Typic Haploxerepts. }\end{array}$ \\
\hline $\begin{array}{c}\text { Located in } \\
\text { backslope position }\end{array}$ & $\begin{array}{c}\text { Fine, mixed, active, mesic, Typic } \\
\text { Haploxeralfs. }\end{array}$ \\
\hline $\begin{array}{l}\text { Located in toeslope } \\
\text { position }\end{array}$ & $\begin{array}{l}\text { Fine-silty, mixed, superactive, mesic, } \\
\text { Typic Haploxerolls. }\end{array}$ \\
\hline
\end{tabular}

\section{CONCLUSIONS}

This study distinguished soil properties and typology relation with slope position in Arasbaran forest. According to obtained results, soil properties such as profile and solum thickness, clay percent of A and B horizons, organic carbon content, total nitrogen and cation exchange capacity identified as data set which can be used in this forest for management based on topographic decisions. Meanwhile the unusual catenary evolution of soil demonstrated soil evolution along altitudinal transect in forest ecosystems are different from other ecosystems due to spatial forest vegetation. Also in this study additional outcome refers to various role and influence of same forest stand in different slope positions. Finally it can be concluded that it is necessary to consider both topography and vegetation effect over the area for forest soil management program, even if one of them is constant. To complete this study, it is recommended to assess all factors which influence on soil evolution using appropriated multivariate analysis. Also soil micromorpology and mineralogy studies can be useful to determine different aspect of soil changes in study area for following management decisions.

\section{REFERENCES}

[1] H. Jenny, Factors of Soil Formation-A System of Quantitative Pedology, Dover, 2011.

[2] S. V. Ollinger, M. L. Smith, M. E. Martin, R. A. Hallett, C. L. Goodale, and J. D. Aber, "Regional variation in foliar chemistry and $\mathrm{N}$ cycling among forests of diverse history and composition", Ecology, vol.83, pp. 339-355, 2002.

[3] E. J. Plaster, Soil Science and Management, 6ed., Delmar Cengage Learning, 2013.

[4] F. Khormali, Sh. Ayoubi, F. Kananro Foomani, A. Fatemi, and Kh. Hemmati, "Tea yield and soil properties as affected by slope position and aspect in Lahijan area, Iran", International Journal of Plant Production, vol. 1(1), pp. 99-111, 2007.

[5] F. B. Pierson, and D. J. Mulla, "Aggregate stability in the Palouse region of Washington: Effect of landscape position", Soil Science Society of American Journal, vol. 54(5), pp. 1407-1412, 1990.

[6] Y. Chen, M. Song, and M. Dong, "Soil properties along a hill slope modified by wind erosion in the Ordos Plateau semi-arid China", Geoderma, 106(3-4), pp. 331-340, 2002.

[7] R. T. Venterea, G. M. Lovett, P. M. Groffman, and P. A. Schwarz, "Landscape patterns of net nitrification in a northern hardwood conifer forest", Soil Science Society of American Journal, vol. 67(2), pp. 527-539, 2003.

[8] P. J. Bohlen, P. M. Groffman, C. T. Driscoll, T. J. Fahey, and T. G. Siccama, "Plant - soil -microbial interactions in a northern hardwood forest", Ecology, vol. 82(4), pp. 965-978. 2001. 
[9] W. L. Daniels, L. W. Zelazny, and C. J. Everett, "Virgin hardwood forest soil of the southern Appalachian Mountains: II. Weathering, mineralogy, and chemical properties", Soil Science Society of American Journal, vol. 51(3), pp. 730- 738, 1987.

[10] U.Anwar, "Soil moisture patterns and hydraulic properties associated with alternative biomass cropping systems across a landscape gradient", M. Eng. thesis, Iowa State University, Iowa, American, 2014

[11] Ch. Ch. Tsui, Z. S. Chen, and Ch. Fu. Hsieh, "Relationships between soil properties and slope position in a lowland rain forest of southern Taiwan", Geoderma, vol. 123, pp. 131-142, 2004.

[12] B. P. Bhaskar, J. P. Mishra, V. Baruah, S. Vadivelu, T. K. Sen, P. S. Butte, and D. P. Dutta, "Soils on Jhum cultivated hill slopes of Narang - Kangripara watershed in Meghalaya", Journal of Indian Society of Soil Science, vol. 52, pp. 125-133, 2004.

[13] A. Darvishzadeh, Geology of Iran, Amir Kabir- Iran (In Persian), 1991.

[14] IRIMO, Country climate analysis. In: Islamic Republic of Iran Meteorological Organization, Tehran, 2011.

[15] P. J. Schoeneberger, D. A. Wysocki, E. C. Benham, and Soil Survey Staff., Field book for describing and sampling soils, Version 3.0. Natural Resources Conservation Service, National Soil Survey Center, Lincoln, NE, 2012.

[16] G. W. Gee, and D. Or, Particle-size analysis, Pp.255-293, In: J. H. Dane, and G. C. Topp, Eds., Methods of soil analysis, Part 4: Physical methods, Agronomy Monograph, vol. 9. ASA and SSSA, Madison, WI, 2002.

[17] J. D. Rhoades, Salinity: Electrical conductivity and total dissolved solids, Pp.417-435, In: D. L. Sparks, Ed., Methods of Soil Analysis, Part 3: Chemical Methods, Agronomy Monograph, vol. 9. ASA and SSSA, Madison, WI, 1996.

[18] G. W. Thomas, Soil $p H$ and soil acidity, Pp.475-490, In: D. L. Sparks, Ed., Methods of Soil Analysis, Part 3: Chemical Methods, Agronomy Monograph, vol. 9. ASA and SSSA, Madison WI, 1996.

[19] D. W. Nelson, and L. E. Sommers, Total carbone, organic carbone, and organic matter, Pp.961- 1010, In: D. L. Sparks, Ed., Methods of soil analysis, Part 3: chemical methods, Agronomy Monograph, vol. 9. ASA and SSSA, Madison, WI, 1996.

[20] C. A. Bower, R. F. Reitemeier, and M. Fireman, "Exchangeable cation analysis of saline and alkali soils", Journal of Soil Science, vol.73, pp. 251-261, 1952

[21] R. H. Loeppert, and D. L. Suarez, Carbonate and gypsum. Pp. 437474, In: D. L. Sparks, Ed., Methods of Soil Analysis, Part 3: Chemical Methods, Agronomy Monograph, vol. 9. ASA and SSSA, Madison, WI, 1996.

[22] J. M. Bremner, Nitrogen-total, Pp. 1085-1121, In: D. L. Sparks, Ed., Methods of Soil Analysis, Part 3: Chemical Methods, Agronomy Monograph, vol. 9. ASA and SSSA, Madison, WI, 1996.

[23] S. Kuo, Phosphorus. Pp. 869-920, In: D. L. Sparks, Ed., Methods of Soil Analysis, Part 3: Chemical Methods, Agronomy Monograph, vol. 9. ASA and SSSA, Madison, WI, 1996.

[24] P. A. Helmke, and D. L. Sparks, Lithium, Sodium, Potassium, Rubidium and Cesium, Pp. 551-574, In: D. L. Sparks, Ed., Methods of Soil Analysis, Part 3: Chemical Methods, Agronomy Monograph, vol. 9. ASA and SSSA, Madison, WI, 1996.
[25] USDA and Soil Survey Staff., Keys to Soil Taxonomy, 11th ed., U.S Department of Agriculture, Soil Conservation Service, Washington, DC., 2010.

[26] F. J. Young, and R. D. Hammer, "Soil - landform relationships on a loess - mantled upland landscape in Missouri", Soil Science Society of American Journal, vol. 64, pp. 1443-1454, 2000.

[27] F. A. Ovalles, and M. E, Collins, "Soil - landscape relationships and soil variability in north central Florida", Soil Science Society of American Journal, vol. 50, pp. 401-408, 1986.

[28] L. R. Drees, L. P. Wilding, P. R. Owens, B. Wu, H. Perotto, and H. "Sierra, Steep land resources: characteristics, stability and micromorphology", Catena, vol: 54(3), pp. 619- 636, 2003.

[29] M. Barbour, T. K. Wolf, and A. A. Schoenherr, Terrestrial Vegetation of California, 3rd ed, University of California, 2007.

[30] P. V. Krasilnikova, N. E. G. Calderona, S. N. Sedovb, E. V. Gomezb, and R. R. Belloa, "The relationship between pedogenic and geomorphic processes in mountainous tropical forested area in Sierra Madre del Sur, Mexico", Catena, vol: 62(1), pp. 14- 44, 2005.

[31] Z. Y. Hseu, H. Tsai, H. C. Hsi, and Y. C. Chen, "Weathering of clay minerals in soils along a serpentinitic toposequence", Clay and Clay Minerals, vol. 55(4), pp. 389-401, 2007.

[32] M. A. Long, "Tree species composition and Oak competitives status in uoland hardwood stands approaching midrotation in Southern Illinois", M. Sc. thesis, Department of Forestry, Southern Illinois University Carbondale, Apr. 2007.

[33] H. L. Bohn, R. A. Myer, and G. A. O'Connor, Soil Chemistry, 2nd ed, Wiley, 2001.

[34] B. Bezabih, M. lemenih, and A. Regassa, "Soil fertility status as affected by different land Use types and topographic positions: a case of delta sub-watershed, southwestern Ethiopia", Journal of Biology, Agriculture and Healthcare, vol. 4, pp. 91- 105, 2014.

[35] L. P. Wilding, N. E. Smeck, and G.F. Hall, Pedogenesis and soil taxonomy, 1st ed, Elsewier science, 1983.

[36] F. J. Young, and R. D. Hammer, "Soil-landform relationships on a loess-mantled upland landscape in Missouri", Soil Science Society of America Journal, vol. 64(4), pp. 1443-1454, 2000.

[37] M. A. Wilson, S. J. Indorante, B. D. Lee, L. Follmer, D. R. Williams, B. C. Fitch, W. M. McCauley, J. D. Bathgate, D. A. Grimley, and K. Kleinschmidt, "Location and expression of fragic soil properties in a loess-covered landscape, southern Illinois, USA", Geoderma, vol. 154(3-4), pp. 529-543, 2010.

[38] K. R. Olson, R. L. Jones, and J. M. Lang, "Soil formation at Millstone Bluff and Johnson Ridge in southern Illinois", Soil Science, vol. 170, pp. 457-468, 2005.

[39] O. S. Nyambane, and S. K. Mwea, "Root tensile strength of 3 typical plant species and their contribution to soil shear strength; a case study: Sasumua Backslope, Nyandarua District, Kenya", Journal of Civil Engineering Research and Practice, vol. 8(1), pp. 57-73, 2011.

[40] T. E. Fenton, Mollisols, In: L. P. Wilding, N. E. Smeck, and G. F. Hall, Eds., Pedogenesis and soil taxonomy II. The soil orders. Elsevier, Amsterdam, Netherlands, pp. 125-163, 1983.

[41] C. Aydinalp, "Some important properties and classification of Mollisols in north western Turkey", Journal of Central European Agriculture, vol. 4(3), pp. 221-224, 2003. 